\title{
How Have Policy Makers Responded to the Current State of ICT in Schools in Saudi Arabia? A Qualitative Investigation
}

\author{
Abdulwahab Alharbi \\ University of Glasgow, Robert Owen Centre for Educational Change, U.K.
}

Keywords: $\quad$ Ministry of Education, Education Authority, ICT, Support.

\begin{abstract}
Previous research into Information and Communication Technology (ICT) in Saudi schools has not considered the role of the Ministry of Education or the Education Authority (EA). As a researcher, I decided to study their role in an attempt to understand the current state of ICT in Saudi schools from the perspectives of policy makers from both bodies. The aim of the study resulted in the generation of the following research question: What are the policy makers' views about the current state of ICT in education in Saudi Arabia? As this research aims to discover and understand the current state of ICT in schools from the views and perspectives of policy makers, a qualitative methodology has been employed and interviews were used to collect the data. In total, five policy makers from both the Ministry of Education in KSA and the local education authority in Ar-Rass city participated. The findings show that the Ministry of Education and the education authority are significant factors in the failure of ICT in schools. The study concludes that, in order to handle issues that affect the successful use of ICT in education, departments of education need to develop their policies, strategies, plans and frameworks.
\end{abstract}

\section{INTRODUCTION}

Developments in information and communication technology (ICT) over the past decades have led to significant changes in the global economy and also to changes in the way countries, people and companies communicate in order to do business (Bhagwati, 2004; Sachs, 2005; Soros, 2002; Stiglitz, 2002, cited by Kozma, 2005). Since education is perceived as the most vital and significant factor in the development of any country as it is believed to be the first step to reach other sectors of society (UNESCO, 2005; Kozma, 2005; Almalki, 2013; The World Bank, 2015), countries around the word, including the Kingdom of Saudi Arabia, have invested a large amount of funds in ICT in education, aiming to improve education in order to produce more educated, innovative and creative people to participate in their country's successful future.

However, many studies reveal diverse factors affecting the successful use of ICT in education in Saudi Arabia. Therefore, and in light of the literature reviewed, this paper aims to understand the current situation of using ICT in schools in the views of policy makers working in the Ministry of Education, the first body responsible for ICT integration in education, who could provide significant details about this issue. When considering the issue addressed in this paper, several and multiple factors affecting the use of ICT in education seem to emerge, and consequently, this could important for any stakeholders involved or interested in the use of ICT in education.

Among the most significant factors affecting teachers in regard to their use of ICT in education are those relating to educational and ICT policies, which are crucial issues that need to be considered. For example, Alissa (2009) has criticised the educational system and its development policies in KSA and has suggested that a number of issues have been causing the failure of education projects; these issues include the absence of a clear political vision and the lack of good management. Consequently, the implementation of any ICT initiatives always seems to be a major factor in the failure of these interventions. Amoudi and Sulaymani (2014) have stressed the necessity of acknowledging the complexity of ICT implementation in the context of Saudi Arabia. This is true, since simply transferring ICT into educational practice does not necessarily mean it will be used correctly and efficiently. Other local studies add that, although teachers are perceived to be the major engine of a school, ICT resources are 
also a significant factor in creating a more successful and effective educational environment (Salem, 2004). This is supported by another Saudi study, conducted by Alsulaimani (2012), who found that a lack of ICT resources available in school considerably hinders the effectiveness of their use.

In addition to these factors, training programmes need to train teachers not simply to be ICT skilled, but rather on ICT skills related to pedagogy for an effective teaching and learning process (Alenezi, 2015). ICT training programmes need to be included in teachers' education programmes as a significant part of preparing future teachers for a more technological teaching and learning environment. Koehler and Mishra (2009) and Jaiya (2015) emphasise the significant role of teachers' education in terms of preparing them to effectively use ICT in their future careers; this can be through training teachers more effectively in terms of practices of pedagogy, ICT skills and knowledge of their subject.

The findings of a Saudi study conducted by Alenezi (2015) revealed another important factor, which is that a lack of immediate technical support and continuous maintenance of available technology in schools substantially hinders teachers' success in the use of technology and its outcomes. In the Saudi context, research conducted by Albugami (2015) found technical support in ICT was not suitable, which underlines the necessity of providing all means of required support for ICT use. A conclusion drawn by Almulhim (2014) suggests another hindering factor, which is the high level of workload assigned for teachers by the school management, which then subsequently affects their use of technology because they do not have time to learn about and with ICT if this is the case.

\section{METHODOLOGY}

As this research aims to discover and understand the current state of ICT in schools from the views and perspectives of policy makers in Saudi Arabia, the following research question was devised: What are the policy makers' views about the current state of ICT in education in Saudi Arabia? In order to answer this question, a qualitative methodology has been employed and interviews were used for the data collection. In total, five policy makers from both the Ministry of Education in KSA and the local education authority in Ar-Rass city participated.

\section{FINDINGS AND DISCUSSION}

This section splits into categories relating to the significant themes extracted from the policy makers' answers. It was important to start with the present ICT situation within policies and plans relating to education, moving to the next theme, which considers the role of people who should be involved in many educational initiatives; before moving to other themes which consider the supportive factors and the failures in ICT interventions.

It is important to note that the policy makers' answers have been summarised altogether for the study relevance purpose.

\subsection{The Current State of ICT in the Educational Policy and Plans}

Policy makers in the MOE stated that the main focus and aims for any plan and project in education come from the national plans that require (in general) all the state's ministries to keep up with overall global developments as well as in regard to the use of technology; and, in particular, the Ministry of Education (MOE) for the continuous development in education and the learning and teaching process as the general education policy aims for the same. The ministry in turn is responsible for the planning and provision of any project-related needs. However, this response was contradicted by another response regarding the current situation of ICT in schools, with the respondent revealing that the ministry does not have such information, as the educational authorities (EAs) are responsible for school visits for any assessment and evaluation after the projects have been introduced to the EAs by MOE. However, most schools should have the required equipment and each EA should have introduced the necessary induction and training for any projects released by the ministry. Thus, these responses confirm the lack of MOE's relation to its other related departments, which also may indicate that accountability is an important factor in the failure of ICT use in education. It was observed that IT-related departments were working together on everything specified for technology in education, such as plans for projects. However, participants noted that now a number of departments had the title of IT but many of them are no longer related to IT in the teaching and learning process. Thus, participants found that as a significant reason of not giving a number of important information, as one said, "That is why we do not have the information you need as we are no longer working together." Thus, they had little experience or awareness about what exactly is 
happening at schools in terms of using ICT. One confirmed that, "We do not make visits to schools but our educational authorities and their related sectors should check that when they visit schools". Another participant argued, "...but mostly we do not receive their feedback of what actually happens in practice. However, from the information we have there are different educational authorities who are enthusiastic for planning and implementing new and different ICT programmes at schools."

Since this section concerns MOE's policies and plans, it is important to point out that it would gain in more significance if I had been able to access ICT policies to gain more understanding for the purposes of this research. I had attempted, using different methods, to access ICT policy documents, which should be clearly stated and operated as what we call policies in Saudi Arabia, but I failed to access any policy documents related to ICT. One of the top five participants admitted clearly that, "There are no available documents [that] can help your research as most of the documents we have are specific documents for us to work on the IT background in the ministry and the priority is always for the ministry and its related departments and schools websites and portals. Actually, we are not lonely on the responsibility of ICT integration in schools as that is planned by the government and all ministries are required to consider this as the development plan in their ministries and related sectors." Another participant stated that, "Honestly, we may have some [policy documents] but they are very confidential and not to be shown [to anyone other] than people who have the right of access to such documents."

\subsection{The Role of Stakeholders}

A number of roles for different stakeholders emerged and were discussed, as follows.

\subsubsection{The Role of the MOE}

According to the government requirements in regard to ICT in education, the ministry's ICT plans depend on these set requirements. Before the ministry requires any school to implement any project, "We require educational authorities to introduce these projects to the supervisors [EAs' school subject leaders], who should then deliver the necessary Training to Teachers."

\subsubsection{The Role of the Educational Authorities}

They receive confirmation about any projects and requests for training stakeholders. Those stakeholders should then train teachers about any new project. The EAs carry out maintenance jobs for any schools in the same region upon a head teacher's request. EAs arrange visits to schools if the schools have any concerns or queries about ICT. IT supervisors visit the schools to assess and evaluate the status and the use of ICT. However, these visits usually only happen after a request from a school, which makes the role of the school management team more difficult in dealing with ICT issues.

\subsubsection{The Role of School Management}

Responses from EA participants highlighted the head-teachers' role, as they should request any ICTrelated resources required in the schools. Another part of their role is to encourage teachers to register for ICT training programmes available at the training centres in the EAs. They should also monitor the situation and the real practice of ICT in their school, and then report that to the local EA.

\subsubsection{The Role of Teachers}

Most projects consider the development of the teaching and learning process. However, in terms of teachers' role in the project plans, EA and policy makers admitted that teachers are not involved. Teachers should join the training course available at the training centre in the EA or in the resources room centre available in the schools. As one of their ICTrelated roles, they should use ICT resources that are available at school in their teaching.

\subsection{Training Opportunities}

- The embassy requires EAs to provide training to teachers as many teachers still prefer the traditional methods of teaching. Each school must have one teacher assigned only for the resources room centre where the necessary ICT resources are available.

- However, the EAs have clarified the state and nature of this training as:

1. Most of those teachers are not experts in the field of technology and do not have adequate skills as originally they taught other school subjects but have now undertaken a course in the resources rooms. However, these courses are inadequate and do not cover all the necessary 
training for ICT in education. Thus, on the other side, this would result in a lack of training opportunities for teachers as well.

2. They revealed that there are very few courses during the academic year.

3. However, because of their workload, teachers are usually not interested in joining these training courses, for a number of reasons, such as:

a. They are not paid by the ministry (no appreciation or rewards) for training during school time nor for courses taken outside of school hours (if there are any).

4. These training courses are completely optional and only a few teachers are willing to attend. They gave the interactive white board (IWB) as an example. The general manager of an IT department admitted the failure of the IWB during the past years, especially in terms of training availability. He said the embassy simply notified them that the IWBs would be delivered to schools and told them to ensure that the schools used them once they were installed, without any training being available concerning their use.

\subsection{Resources}

In terms of the actual condition of the IT environment in schools, the EA participant admitted: "We are definitely aware about this issue but it is not our responsibility to change these non-working and old resources without a formal request made by school management". They felt that some head teachers did not request new resources in order to avoid any accountability issues that might arise if the EA knew that they were not using technology in their schools.

The EA has IT supervisors who visit schools to check if they need any maintenance or want to report any issues related to ICT in the school in general. I asked the participant, "If you have a maintenance team visiting schools and they can see all the issues as most of the resources are visible, why does the EA not take action in this case and make the change even if the school head teachers do not want to request them escaping from the accountability? " He replied:

"Because we are sure if do this action, those head teachers will require us to provide them with appropriate training courses to learn how to use these types [of resources] and learn any new [techniques] they are not aware about. In this case, we could not accept such requests as the first responsible body for that is the ministry; they need to organise and prepare effective courses and pay for resources and for any stakeholders, so we can do the job if everything is available."

\subsection{Failure of Development Projects for General Education Stages}

Policy makers stated that the ministry has a number of ICT projects and it works on implementing them. However, the usual issues concerning the success of these projects relate to the education authorities and their schools, as the MOE could not be responsible for the EAs neglect and carelessness in implementing the ministry's projects. An example is the King Abdullah project for educational development in 2007 when each student and teacher was provided with laptop devices. The government provided a good budget for this project, but admitted that it had failed and no longer existed. What happened was that the integration of technology in this project was only part of the educational development plan in general and it was only implemented in a few selected schools in each region in the country; in addition, from different stakeholders in the ministry did not put any thought into the technology and thus the devices were not used. Therefore, these devices were collected again by the project officials from the selected schools.

\subsection{Some Issues Related to ICT Use in Education}

a. The ministry provides expensive resources to implement most projects only in selected schools in each region of the country. Then, if the project has succeeded and there are enough funds available, it can be expanded to other schools, as planned. Otherwise, the project might not have the potential and attention as it was and might be cancelled. This is one reason why some projects are cancelled or suspended until further notice.

b. Provision of new resources in some schools for the same issue above. However, sometimes is not only because of funds but because the provision of new resources is wasting the ministry's budget when it is spent on schools that have not used the old resources.

c. Maintenance issues, as each educational authority is only allowed to employ a specific number of people for team maintenance, which is not enough, as each authority has at least 300 schools or more. In terms of assigning maintenance staff in each school, this has been impossible so far. 
d. Teachers' development: the ministry provides some courses, but EAs may lack the means to advertise or deliver these courses. In addition, the majority of teachers have not welcomed this idea as they are not paid for out of hours' work.

e. Teachers' skills: as the training is always optional and because teachers are not motivated or rewarded financially or at least with a reduction in their daily work hours, large numbers of teachers are not interested in improving their ICT skills or undertaking basic courses to improve their ICT skills. In addition, age and in-service experience play an important role in relation to teachers' lack of ICT skills, as the majority of Saudi teachers with more than 10 years of service did not study any IT subject in their own education, except those who specialised in IT at university.

f. Teachers and students' acceptance of and attitude towards the use of ICT is also an issue, and here we need to educate them about the benefits that the use of ICT can provide for their teaching and learning.

\section{CONCLUSIONS}

There are many hindering factors in relation to the use of ICT in education. The findings presented in this paper have shown a number of the factors that most affect the successful use of ICT in Saudi schools. However, factors related to the Ministry of Education cause most of these obstacles. Therefore, it can be concluded that initiatives and actions from educational departments no doubt have a significant influence on the success or failure of ICT integration in education; and, in order to minimise issues such as those revealed in the present paper, more efforts and attention are required from the organisational-level departments of education for developing their policies, strategies, plans and frameworks.

It is important to indicate that, in regard to the research question, which considers the policy makers' views in order to understand the current state of ICT in education, it would have been helpful if I had been able to access ICT policies to gain more understanding for the purposes of this research. I did attempt to gain wide access to ICTs - which should be clearly stated and operated as what we call policies in Saudi Arabia - through different ways including literature, the Ministry of Education and its related sectors and organisations' websites and publications, and face-to-face meetings with policy makers and other people in the Ministry. However, despite all these attempts, I failed to access or gain information on any policy required for this study. In particular, during my fieldwork for the collection of this study data, I met the policy makers themselves, who refused to share any policy or even strategies with the researcher as they admitted that the ministry lacks a clear and standard policy specifically for ICT.

There is some local research where ICT policy may be found; however, in reality, most of this is usually taken from objectives of different plans or projects, and, although researchers call them policies, this is not true - unlike in the case of my study. No single article on the general educational policy in Saudi Arabia mentions ICTs, but other plans, programmes and projects may set up a number of objectives. However, these initiatives cannot reflect the policy we mean in this study, as a number of ICT interventions in the Saudi context have been cancelled or postponed or have even failed. The findings of the study will provide more details about this crucial issue.

Therefore, I have instead decided to interview ICT policy makers from departments related to the Ministry of Education to understand the current state of ICT in education from their perspectives, which will in turn give us more understanding of the use of ICT by teachers in the light of their views and help shape the aims of the present study. In addition, this research will benefit from the available literature in regard to the Ministry's different ICT interventions, which should be very useful in the discussions in this thesis. In this research, Policy Makers is used as a term to refer to those who work in high positions in related divisions in the ministry, and are the highestlevel representatives of the ministry's decisions regarding ICT initiatives.

\section{ACKNOWLEDGEMENTS}

I am grateful to Dr. Oscar Valiente and Prof. Michele Schweisfurth for their continuous support throughout my research.

\section{REFERENCES}

Al Mulhim, E. 2014. The Barriers to the Use of ICT in Teaching in Saudi Arabia: A Review of Literature. Universal Journal of Educational Research, 2 (6), pp. 487-493. 
Albugami, S., and Ahmed, V. 2015. Success factors for ICT implementation in Saudi secondary schools: From the perspective of ICT directors, head teachers, teachers and Students. International Journal of Education and Development using Information and Communication Technology, 11 (1), pp. 36-54.

Alenezi. A. 2015. Influences of the Mandated Presence of ICT in Saudi Arabia Secondary Schools. International Journal of Information and Education Technology, 5 (8), pp. 638-644.

Alissa, A. (2009). Educational reform in Saudi Arabia. Beirut: Dar al-saqi publishing.

Almalki, G., Finger, G., and Zagami, J. 2013. Introducing SMART Table Technology in Saudi Arabia Education System. International Journal of Advanced Computer Science and Applications, 4 (2), pp. 46-52.

Alsulaimani, A. (2012). What Impedes Saudi Science Teachers from Using ICT? Journal of Education and Practice, 3 (12), pp. 146-155.

Amoudi1, K., and Sulaymani, O. 2014. The integration of educational technology in girls' classrooms in Saudi Arabia. European Journal of Training and Development Studies, 1 (2), pp.14-19.

Bhagwati, J. (2004). In defense of globalization. Oxford, UK: Oxford University Press.

Jaiya, A. 2015. ICT and teachers education. Golden Research Thoughts, 4 (12), pp. 1-8.

Koehler, M., \& Mishra, P. 2009. What is technological pedagogical content knowledge (TPACK)? Contemporary Issues in Technology and Teacher Education, 9 (1), pp. 60-70.

Kozma, R. 2005. National policies that connect ICT- based education reform to economic and social development. An Interdisciplinary Journal on Humans in ICT Environments, 1 (2), pp. 117-156.

Sachs, J. (2005). The end of poverty: Economic possibilities of our time. New York: Penguin Press.

Salem, A. (2004). Educational technology and e-learning. Riyadh: Alrushd Publication.

Soros, G. (2002). On globalization. New York: Public Affairs.

Stiglitz, J. (2002). Globalization and its discontents. New York: Norton.

The World Bank. (2015). Education overview. Available at: http://pubdocs.worldbank.org/pubdocs/publicdoc/2015 /9/53191442946249039/Education-OverviewSEP22.pdf [Accessed 13 May 2016].

UNESCO. (2005). Teacher involvement in educational change. PRELAC Journal. 